\title{
Differentially displayed expressed sequence tags in Melipona scutellaris (Hymenoptera, Apidae, Meliponini) development
}

\author{
FLÁVIA A. SANTANA ${ }^{1}$, FRANCIS M.F. NUNES ${ }^{2}$, CARLOS U. VIEIRA ${ }^{1}$, \\ MARIA ALICE M.S. MACHADO ${ }^{1}$, WARWICK E. KERR ${ }^{1}$, \\ WILSON A. SILVA $\mathrm{Jr}^{2}$ and ANA MARIA BONETTI ${ }^{1}$ \\ ${ }^{1}$ Universidade Federal de Uberlândia, Instituto de Genética e Bioquímica, Laboratório de Genética, \\ Campus Umuarama, Bloco 2E sala 33, rua Acre s/n, 38400-902 Uberlândia, MG, Brasil \\ ${ }^{2}$ Departamento de Genética, Faculdade de Medicina de Ribeirão Preto, Universidade de São Paulo, \\ Av. Bandeirantes 3900, 14040-900 Ribeirão Preto SP, Brasil
}

Manuscript received on January 31, 2005; accepted for publication on August 31, 2005; contributed by WARWICK E. KERR*

\begin{abstract}
We have compared gene expression, using the Differential Display Reverse Transcriptase - Polymerase Chain Reaction (DDRT-PCR) technique, by means of mRNA profile in Melipona scutellaris during ontogenetic postembryonic development, in adult worker, and in both Natural and Juvenile Hormone III-induced adult queen. Six, out of the nine ESTs described here, presented differentially expressed in the phases L1 or L2, or even in both of them, suggesting that key mechanisms to the development of Melipona scutellaris are regulated in these stages. The combination HT11G-AP05 revealed in L1 and L2 a product which matches to thioredoxin reductase protein domain in the Clostridium sporogenes, an important protein during cellular oxidoreduction processes. This study represents the first molecular evidence of differential gene expression profiles toward a description of the genetic developmental traits in the genus Melipona.
\end{abstract}

Key words: Melipona scutellaris, gene expression, DDRT-PCR.

\section{INTRODUCTION}

Except for Apis mellifera, the knowledge about biological, cellular, and molecular traits in Hymenoptera is still meager, although they are an excellent model for studying social characteristics, behavior, neurobiology, development, and gene expression regulation. For Apis mellifera, it is known that differences in food quality during the larval period determine the caste phenotypes. There are differentially expressed genes, both in queens and workers, which are involved in that mechanism. On

*Member, Academia Basileira de Ciências Correspondence to: Flávia Assumpção Santana

E-mail: fassantana@yahoo.com.br the other hand, in Melipona, the caste determination is decisively influenced by a genetic predisposition. Diploid larvae will become queens or workers; brood cells are operculated soon after the egg is laid, eliminating in this way any possibility of differential feeding (Kerr 1950). Some studies were reported based on phenotypic differences associated with Juvenile Hormone ( $\mathrm{JH})$ topical administration. When applied to larvae from genus Melipona, this hormone promotes the appearance of complete female (queen) features (Campos 1978, Bonetti 1983, 1984, Bonetti et al. 1995). Genes up- or downregulated in response to $\mathrm{JH}$ during the Melipona development are still to be identified. 
The identification of differentially expressed genes has been used to understand the function of genes and the basic molecular mechanisms of distinct biological processes (Vedoy et al. 1999). Differential display reverse transcriptase - polymerase chain reaction (DDRT-PCR) has innovated the gene expression field (Liang and Pardee 1992). This is an easy, widely employed and reliable PCR-based method used to detect differentially expressed genes in cells, tissues, and organisms (Warthoe et al. 1995, Liu and Raghothamna 1996, Poirier et al. 1997). Using this approach, Hepperle and Hartfelder (2001) identified, in honeybee queens and workers, an FtzF1 homolog and a Cut-like transcript, two strong candidates to participate in processes like the metamorphic ecdysone response cascade regulation and ovariolos degradation, respectively.

In this work, the DDRT-PCR technique was used to study differential gene expression profiles during post-embryonic development of Melipona scutellaris. The differentially expressed cDNA fragments detected were cloned, sequenced and analyzed by comparison using public databases. The results reported here are the first pieces of evidence of differential gene expression profiles in Melipona scutellaris during its ontogenetic development.

\section{MATERIALS AND METHODS}

\section{BIOLOGICAL MATERIAL}

Stingless bees Melipona scutellaris come from Bahia, Brazil, and were kept in Meliponário Uberlândia, Uberlândia - MG, Brazil (S 180 55' / W $480^{\circ} 17^{\prime}$ ). Larvae of different stages were used: larva 1 (L1), larva 2 (L2), larva 3 (L3), predefecating (LPD) and defecating (LD); pupae from workers (WP) and queens (QP); and adults: newborn workers (AW), natural virgin queens (AQ) and JH III (Sigma) -induced virgin queen (AIQ). The samples were collected, put immediately in liquid nitrogen and preserved at $-80^{\circ} \mathrm{C}$. Just before RNA extraction they were allowed to thaw in ice.

\section{RNA EXTRACTION}

Total RNA of whole body was extracted using TRIzol reagent (Invitrogen) following the recommended instructions and was treated with DNase I (Invitrogen). RNA quality was verified in $1 \%$ agarose gel electrophoresis

SCREENING FOR DIFFERENTIAL EXPRESSION BY DDRT-PCR

Reverse transcription reactions were performed in triplicate using $200 \mathrm{ng}$ of total RNA, 8 pmols of one of the oligo-DT primers containing an anchored base (Table I), 12U RNAsin (Amersham Biosciences), 1x RT buffer, $10 \mathrm{mM}$ DTT, $200 \mathrm{mM}$ dNTPs and 200U RT Superscript II (Invitrogen), brought to a final volume of $20 \mu \mathrm{l}$. Reverse transcriptase was not added to negative control, in order to verify possible DNA contamination. PCR amplification was carried out according to the following protocol: $1 \mu \mathrm{L}$ of the RT reaction, $50 \mu \mathrm{M}$ of each dNTP, $1 \mathrm{U}$ Taq DNA polymerase (Invitrogen), 1x buffer, $2.5 \mathrm{mM}$ $\mathrm{MgCl}_{2}, 8 \mathrm{pmol}$ of one of the arbitrary primers (Table I) in a final volume of $20 \mu \mathrm{L}$. cDNA profiles were loaded in $6 \%$ denaturing polyacrylamide gels containing $8 \mathrm{M}$ urea, run at $150 \mathrm{~V}$ for 13 hours. After the electrophoresis, gels were stained with $\mathrm{AgNO}_{3}$ according to Bassan et al. (1991). Bands representing differentially expressed genes were cut out of the gels, the cDNA eluted, and precipitated according to Sambrook et al. (1989). A total of 15 purified fragments with the respective primer combinations, under the same PCR conditions were obtained. Purified fragments were cloned into pUC18 (SureClone Ligation kit, Amersham Biosciences) and competent $E$. coli DH10B-cells were transformed by heat shock. Bacteria were grown in 2x YT medium before aliquots were plated on $2 \mathrm{x}$ YT agar containing ampicillin. Positive clones (white colonies) were picked, grown overnight in 2x YT medium and used as templates for PCR using M13 universal primers (forward: 5'-GTAAAACGACGGCCAGT-3' and reverse: 5'-CAGGAAACAGCTATGAC-3'). Insert amplifications were confirmed checking $2 \mu \mathrm{L}$ of 
PCR products on 1\% agarose gel electrophoresis. Sequencing reactions were performed in both directions, using 3.2 pmol M13 primer (forward or reverse), $2 \mu \mathrm{L}$ Big Dye and $1 \mu \mathrm{L}$ of PCR product, to a final volume of $5 \mu \mathrm{L}$ and submitted to $\mathrm{ABI}$ PRISM 377 DNA automatic sequencer (Applied Biosystems).

TABLE I

Sequences of oligo-dT (HT11) and arbitrary (AP, OPA and OPF) primers employed for DDRT-PCR experiments.

\begin{tabular}{|c|c|}
\hline Primers & Sequence $5^{\prime} \rightarrow 3^{\prime}$ \\
\hline HT11A & AAGCTTTTTTTTTTA \\
\hline HT11C & AAGCTTTTTTTTTTTC \\
\hline HT11G & AAGCTTTTTTTTTTTG \\
\hline AP04 & AAGCTTCTAACG \\
\hline AP05 & AAGCTTAGTAGGC \\
\hline OPA18 & AGGTGACCGT \\
\hline OPA17 & GACCGCTTGT \\
\hline OPA16 & AGCCAGCGAA \\
\hline OPF12 & ACGGTACCAG \\
\hline
\end{tabular}

\section{SEQUENCE ANALYSES}

Eletropherograms were analyzed and assembled with Sequencher 3.1 program. Sequences of at least $180 \mathrm{bp}$ after both vector and quality trimming were considered high-quality ESTs (nine of 15 clones). Nine 3' Expressed Sequence Tags (ESTs) were deposited in dbEST database and were compared to GenBank data using NCBI-Blast algorithms (standard parameters) and to Apis mellifera Genome Project

(http://www.hgsc.bcm.tmc.edu/projects/honeybee/)

version 2.0 (Blast $\mathrm{N}$ algorithms). In some cases, the following NCBI analyses tools were used: 1) $\mathrm{CDD}$, to search conserved domains evidences and 2) Entrez Gene, looking for Gene Ontology terms to annotate functional assignments.

\section{RESULTS}

We tested 18 primer combinations, an example of M. scutellaris expression profile obtained in a polyacrylamide gel is shown in Figure 1. We could verify differences of intensity in fragments during larval stages and also, bands exclusively found only in one of the samples.

Of nine analyzed ESTs (Table II), only 2 sequences, D01 e B03, had significant results for Blast $\mathrm{N}$-EST of humans. By its turn, results from Blast N-nr for five of our ESTs (D01, B03, D08, C07 and B08) presented high similarity with human sequences, mainly chromosomal but, only for D01, B03 and B08, the best Blast X match was correspondent to the same species.

The possibility of contamination with human material during sample manipulation of M. scutellaris was discarded because the technique was rigorously followed and, beyond this, of the only two M. scutellaris ESTs, B03 and B04, that had similarity with the GroupUn.6210 and Group1.45, respectively, in the Apis Genome Assembly version 2.0, the B03 (which matched human) showed highly conserved among bees, with e-value $=1 \mathrm{e}-22$. Melipona sequences that didn't have conclusive matches with the ones deposited in databases were obtained in this study and they could represent genes not yet described.

Six of the nine ESTs described here were differentially expressed in the phases L1 or L2, or even in both of them, suggesting that key mechanisms to the development of M. scutellaris could be regulated in these stages.

The primer combinations HT11G-AP05 revealed differentially displayed product, EST B01, that matched with a thioredoxin-disulphide reductase from Clostridium sporogenes (Blast $\mathrm{X}$ best match result) with e-value equals to $5 \mathrm{e}-15$.

Sequence similarities found in some ESTs will be pointed out due to important terms of Gene Ontology in which such sequences were annotated. The first distinction is respected to EST B03 that, despite the best match by Blast $\mathrm{X}$ did not have func- 


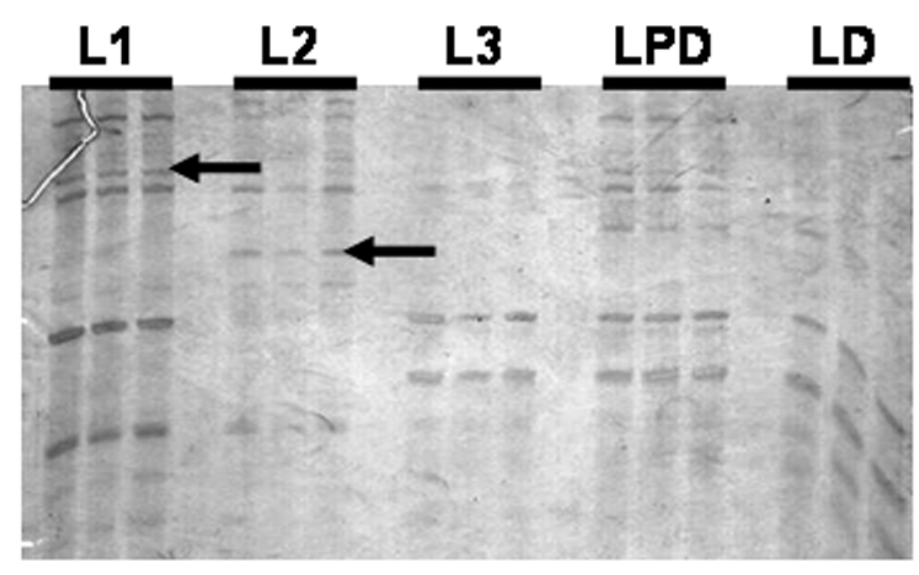

Fig. 1 - Profiles of DDRT-PCR in larval stages of Melipona scutellaris generated using HT11A-AP04 primer combination. 6\% denaturing polyacrylamide gel, stained with $\mathrm{AgNO}_{3}$. Arrows indicate differentially expressed fragments (performed in triplicate) in L1 and L2. The in L1 is respected to EST D01 and in L2 to EST B09. Some bands, not stage-specific, with differences of intensity can also be observed during development. Larvae of different stages: larva 1 (L1), larva 2 (L2), larva 3 (L3), predefecating (LPD) and defecating (LD).

\section{TABLE II}

Summary of information about the nine Melipona scutellaris ESTs differentially expressed. ESTs B03 and B04 show significant similarity with Apis mellifera genome version 2.0, using Blast $\mathrm{N}$ algorithms. Developmental stages: L1 (larva 1), L2 (larva 2), LD (defecating larva), AW (newborn workers), AQ (natural virgin queens) and AIQ (JH III-induced virgin queen).

\begin{tabular}{c|c|c|c}
\hline $\begin{array}{c}\text { EST } \\
\text { identification }\end{array}$ & $\begin{array}{c}\text { GenBank accession } \\
\text { number }\end{array}$ & $\begin{array}{c}\text { Length } \\
\text { (bp) }\end{array}$ & $\begin{array}{c}\text { Developmental } \\
\text { expressed stage }\end{array}$ \\
\hline D01 & CK722151 & 256 & L1 \\
\hline D08 & CK722150 & 212 & L1 and L2 \\
\hline C07 & CK722149 & 690 & LD \\
\hline B03 & CK722148 & 448 & L1 and L2 \\
\hline B01 & CK722147 & 204 & L1 and L2 \\
\hline B09 & CK722146 & 197 & L2 \\
\hline B08 & CK722145 & 469 & L1 and L2 \\
\hline B07 & CK722144 & 248 & AQ \\
\hline B04 & CK722143 & 232 & AQ, AIQ and AW \\
\hline
\end{tabular}

tional classification, this sequence had domain identity with the human domain KOG2424 (e-value = 8e-12), which interacts with RNA polymerase II, involved in transcription star site selection. An- other distinction is EST B04, expressed in queens and adult workers, which presented match with Myocyte enhancing factor 2 (Mef-2), which is classified as RNA polymerase II transcription mediator 
activity. The EST is similar to CAAX prenyl protease 1, described in Drosophila as CG7573 gene product, putatively involved in cell surface receptor linked to signal transduction. The EST B08 presented weak similarity to Signaling Lymphocytic Activation Molecule, described in mammals T-cells surface antigen CD2 proteins, involved in cell-cell adhesion and immune response modulation.

\section{DISCUSSION}

Relatively slight changes in $M$. scutellaris gene expression could be monitored by DDRT-PCR. The data presented here suggest that we detected ESTs that are up- or down-regulated, depending on the developmental stage of this bee. Some ESTs seem to be specifically expressed in one or more stages, suggesting that they can correspond to genes involved in stage or caste determination.

In A. mellifera, the differences already reported (Evans and Wheeler 2001) could reflect, in part, a common impact of regulatory hormones on gene expression in young larvae and in larvae destined to become workers.

We also detected some ESTs which play housekeeping roles, with similar or variant band intensity. Evans and Wheeler (1999) found differentially expressed genes in A. mellifera workers and queens, related to metabolic, nutritional, and signaling diverse processes underlying development, potentially involved differentiation processes of female castes and, suggested that distinct morphological phenotypes are based on differential gene expression rather than genetic polymorphism.

Our data lead us to three arguments. The first one may indicate new sequences that for the first time entered public databases. The second premise indicates that such sequences are specific to those species, regulating biological processes restrict to the development of that bee. The third one can possibly indicate that we are not really dealing with potentially coding sequences, because these EST were generated by 3' strategy using oligodT primer, favoring access to non-translated 3' regions (3'UTRs).
Human genome is, by far, the best characterized, with the greater number of sequences deposited in GenBank. The hugely available data for this species may account for a bias in the analyses of little known organisms, like M. scutellaris. Even with genomes of other available insects, such information seemed not enough for us to do, for example, phylogenetic inferences.

Our data reflect the identification of ESTs that may be lacking in the Apis genome, as well as Anopheles and Drosophila. Previous work with $A$. mellifera showed a high level of sequence with weak or no match to the Drosophila genome, predicted proteins or ESTs sequence, but plausible orthologs were found for proteins from human, mouse, and other non-Arthropoda (Whitfield et al. 2002, Kucharski and Maleszka 2002). In the same way, Nunes et al. (2004) also found a set of sequences more similar to mammals (especially humans) than to other vertebrates or invertebrates, indicating that some genes diverged less between social bees and this group.

Lobo et al. (2003) sequenced $81 \mathrm{~kb}$ genomic region from honey bee and, all 13 putative genes described have lacked similarity to known invertebrate or vertebrate data, differences that may show evolution of traits such as social behavior and haplodiploidy. In this context, the similarities found between Melipona ESTs and non-insect sequences cannot be considered artifacts; contrarily, they reflect new biological interpretations and also the need for additional efforts to characterize other genomes. Considering that Apis genome is not yet finished, there are still possibilities that such sequences will soon become more closely shared.

Even with the considerable advance in genomics and transcriptome studies, a lot of largescale gene characterization papers present high rates of transcripts "with no significant similarity found", as well as "without Gene Ontology functional results". Thioredoxin reductase (TrxR) is a flavoprotein that catalyzes the NADPH-dependent reduction of thioredoxin and plays roles in maintaining the redox environment of the cell, being part 
of a system that protects against cytotoxic reactive oxygen species (for review, see Williams Jr 2000). In Drosophila, TrxR acts as an intracellular antioxidant, and mutants for this enzyme have their capacity of cell protection against cytotoxic damage reduced, which results in larvae death. Such mutants have this enzyme reduced; affected pupal eclosion and a diminished life span (Missirlis et al. 2001). A similar enzyme in $M$. scutellaris may be important to the early embryonic development when the food is offered only once (massal feeding) to the newecloded larvae, implicating in an intensive energetic metabolism.

Drosophila Mef-2 is a direct regulator of Actin57B transcription in cardiac, skeletal and visceral muscle lineages and also, based on GO terms; it is involved in cell proliferation, transcription activities and ovarian follicle cell development. Specifically, this last function is in accordance with our findings, because genes that regulate oogenesis during embryogenesis can also perform important roles related to vitellogenesis and physiological processes ascribed to adult females, associated to reproduction and social behavior of the colonies.

The differentiation that occurs in an animal is driven by "TURN ON" and "TURN OFF" genes and, depending on the active genes in a cell, the difference between one cellular type and the other appears. Developing programs depend on signaling and answering cascades, which have been kept highly conserved in the animal kingdom.

In order to disclose these developmental functions and understand differences and similarities among bees, other insects and taxa, we are designing studies using RNA blots, gene-by-gene approach, in situ hybridization, real time PCR and RNAi methods. The analysis proposed in this work shows an overview of genome activity during the development, mainly the larval one. Further approaches are now needed in order to delineate: complete Melipona transcriptome, a novel set of differentially expressed genes, the relationship among novel genes described here and the genetic hierarchy that leads to life cycle regulation.

\section{ACKNOWLEDGMENTS}

Maria Cristina Ramos Costa, Caetano Costa, Karine Sá Ferreira for critical reading of the manuscript. This research was supported by a grant from Coordenação de Aperfeiçoamento de Pessoal de Nível Superior (CAPES), Conselho Nacional de Desenvolvimento Científico e Tecnológico (CNPq), Fundação de Amparo à Pesquisa do Estado de São Paulo (FAPESP) and Fundação Hemocentro de Ribeirão Preto.

\section{RESUMO}

Nesse estudo nós usamos a técnica de Differential Display Reverse Transcriptase - Polymerase Chain Reaction (DDRT-PCR) para comparamos o perfil de mRNA em Melipona scutellaris durante o desenvolvimento ontogenético pós-embrionário e em operárias adultas, rainha natural e induzida pelo Hormônio Juvenil III. Fragmentos diferencialmente expressos foram detectados usando as seguintes combinações de primers: HT11G-AP05; HT11C-AP05; HT11G-OPF12; HT11G-OPA16. Dos 9 ESTs descrito nesse trabalho, 6 tiveram expressão diferencial nas fases de larva L1 e L2, sugerindo serem mecanismos chave no regulação do desenvolvimento larval em Melipona. A combinação HT11G-AP05 revelou em L1 e L2 um produto com similaridade à proteína tioredoxina redutase de Clostridium sporogenes, uma proteína importante durante os processos de oxidoredução. Esse estudo representa as primeiras evidências moleculares do perfil de expressão durante o desenvolvimento ontogenético em abelhas do gênero Melipona.

Palavras-chave: Melipona scutellaris, expressão gênica, DDRT-PCR.

\section{REFERENCES}

Bassan BJ, Caetano-Anoles G and Gresshoff PM. 1991. Fast and sensitive silver staining of DNA in polyacrylamide gels. Anal Biochem 196: 80-83.

BonetTi AM. 1983. Action of Juvenile hormone on gene expression in Melipona (Hymenoptera, Apidae, Meliponinae). Rev Bras Genet 6: 583-585.

Bonetti AM. 1984. Efeitos do Hormônio Juvenil no desenvolvimento ovariano de Melipona quadrifasciata. Rev Bras Biol 44: 509-516. 
Bonetti AM, Kerr WE And Matusita SH. 1995. Effects of Juvenile Hormones I, II and III, in sigle and fractionated dosage in Melipona bees. Rev Bras Biol 55: 113-120.

CAmpos LAO. 1978. Sex determination in bees. VI. Effects of juvenile hormone analog in males and females of Melipona quadrifasciata (Apidae). J Kansas Entomol Soc 51: 228-234.

Evans JD AND WheEler DE. 1999. Differential gene expression between developing queens and workers in the honey bee, Apis mellifera. Proc Natl Acad Sci USA 96: 5575-5580.

EvANS JD AND WHEELER DE. 2001. Expression profiles during honeybee caste determination. Genome Biol 2: RESEARCH0001.

Hepperle C and Hartfelder K. 2001. Differentially expressed regulatory genes in honey bee caste development. Naturwissenschaften 88: 113-116.

KERR WE. 1950. Genetic determination of castes in the genus Melipona. Genetics 35: 143-152.

KUCHARSKi R AND MALESZKA R. 2002. Evaluation of differential gene expression during behavioral development in the honeybee using microarrays and northern blots. Genome Biol 3: RESEARCH0007.

Liang P AND Pardee AB. 1992. Differntial display of eukaryotic Messenger RNA by means of the polymerase chain reaction. Science 257: 967-971.

LiU C And Raghothamna KG. 1996. Practical method for cloning cDNAs generated in mRNA differential display. Biotechniques 20: 576-580.

Lobo NF, Ton LQ, Hill CA, Emore C, RomeroSeverson J, Hunt GJ And Collins FH. 2003. Genomic analysis in the sting-2 quantitative trait locus for defensive behavior in the honey bee, Apis mellifera. Genome Res 13: 2588-2593.
MissiRlis F, PHILliPs JP AND JACKLE H. 2001. Cooperative action of antioxidant defense systems in Drosophila. Cirr Bio 11: 1272-1277.

NunES FMF ET AL. 2004. The use of Open Reading frame ESTs (ORESTES) for analysis of the honey bee transcriptome. BMC Genomics 5(84): 1-12.

Poirier GM, Pyati J, WAN JS AND ERlander MG. 1997. Screening differentially expressed cDNA clones obtained by differential display using amplified RNA. Nucleic Acids Res 25: 913-914.

Sambrook J, Fritsch EF And Maniatis T. 1989. Molecular cloning: a laboratory manual, $583 \mathrm{p}$.

Vedoy CG, Bengtson MH and Sogayar MC. 1999. Hunting for differentially expressed genes. Braz J Med Biol Res 32: 877-884.

Warthoe P, Bauer D, Rohde M and Strau SS. 1995. Detection and identification of expressed genes by differential display. In: PCR Primer: A laboratorial manual. Dieffenbach $\mathrm{CH}$, Dveskler GS. Cold Spring Harbor Laboratory Press, New York, USA.

WhitFiELD CW, BAND MR, BONALDO MF, KuMAR CG, LiU L, PARdinas JR, Robertson HM, SOARES MB AND RobINSON GE. 2002. Annotated expressed sequence tags and cDNA microarrays for studies of brain and behavior in the honey bee. Genome Res 12: 555-566.

Williams JR CH. 2000. Thioredoxin-thioredoxin reductase - a system that has come of age. Eur $\mathrm{J}$ Biochem 267: 6101. 